\title{
Subcutaneous Hematoma following Subcutaneous Emphysema: An Occult Association
}

Sir,

Subcutaneous emphysema resulting from seepage of air into the contiguous subcutaneous tissue planes is classically associated with crepitus on palpation. Other cutaneous changes might include swelling, erythema, pain, infection, and hematoma. ${ }^{[1,2]}$
Subcutaneous hematoma, although an uncommon association can occur due to shearing of the subcutaneous vessels due to tension in the involved tissue. In subcutaneous hematoma, the blood accumulates in the fatty tissue instead of muscle, unlike orthopedic hematoma. Individuals on oral anticoagulants are 


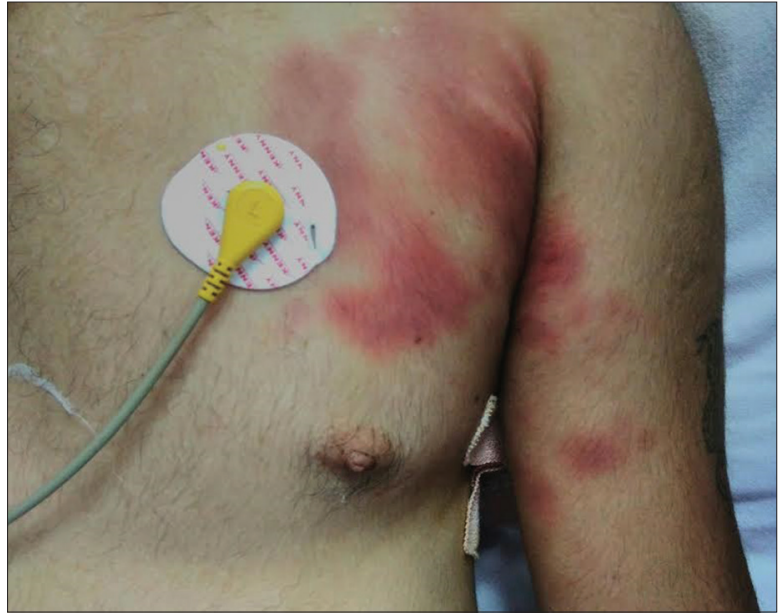

Figure 1: Redness of skin with underlying swelling in the left lateral pectoral region extending into the axilla and inner aspect of arm

more at risk from this type of damage as their blood clotting is already restricted. The same mechanism also holds relevance for the association of pain in such situations.

A 35-year-old male patient admitted to our Neurocritical Intensive Care Unit with severe head injury had undergone percutaneous tracheostomy (PCT) after 6 days of tracheal intubation and mechanical ventilation. Following PCT, the patient developed subcutaneous emphysema as a false tract had been created initially, at the time of PCT. The emphysema started in the cervicofacial region rapidly spreading over the chest, abdomen, both upper limbs, and bilateral thighs. An hour later, the patient developed redness of skin with underlying swelling in the left lateral pectoral region extending into the axilla and inner aspect of arm [Figure 1]. It was also associated with rise in temperature and pain. Gradually, after $6 \mathrm{~h}$, the involved area transformed into purple discoloration. No similar changes were noticed in any other region in the body. The subcutaneous hematoma resolved spontaneously in next 3 days, but subcutaneous emphysema remained there for next 7 days.

The subcutaneous tissue or the hypodermis has a rich innervation of larger blood vessels and nerves. Bleeding from these vessels can typically result in hematomas. In massive subcutaneous emphysema, the presence of air pockets creates a tension predisposing these vessels to rupture. Although uncommon, subcutaneous hematoma when associated with subcutaneous emphysema can be an additional source of pain demanding administration of additional analgesics. This occurs due to stretching of nerve fibers present richly in the hypodermis. Moreover, hematoma itself can be a source of infection. Nevertheless, isolated subcutaneous emphysema have been reported to be associated with infection. ${ }^{[3]}$ The subcutaneous hematoma following subcutaneous emphysema resolves in 2-3 days and completely overcome in 5-10 days. ${ }^{[4]}$ However, nonresolving hematomas should be thoroughly investigated for cause and should be managed accordingly. The most effective treatment for a subcutaneous hematoma is, simply, time. If the hematoma is large and causing a lot of pain and inhibition of mobility, it may have to get it drained. Our case highlighted the possible complication of subcutaneous hematoma due to subcutaneous emphysema that may occur following PCT.

\section{Financial support and sponsorship}

Nil.

\section{Conflicts of interest}

There are no conflicts of interest.

Ankur Khandelwal, Indu Kapoor, Hemanshu Prabhakar, Charu Mahajan Department of Neuroanaesthesiology and Critical Care, Neuroscience Centre, All India Institute of Medical Sciences, New Delhi, India

Address for correspondence: Dr. Indu Kapoor, Department of Neuroanaesthesiology and Critical Care, Neurosciences Centre, All India Institute of Medical Sciences, New Delhi - 110 029, India. E-mail: dr.indu.me@gmail.com

\section{RefERENCES}

1. Maunder RJ, Pierson DJ, Hudson LD. Subcutaneous and mediastinal emphysema. Pathophysiology, diagnosis, and management. Arch Intern Med 1984;144:1447-53.

2. Vargo RJ, Potluri A, Yeung AY, Aldojain A, Bilodeau EA. Cervicofacial subcutaneous emphysema: A clinical case and review of the literature. Gen Dent 2016;64:68-71.

3. Feinstone T. Infected subcutaneous emphysema: Report of case. J Am Dent Assoc 1971;83:1309-11.

4. Gamboa Vidal CA, Vega Pizarro CA, Almeida Arriagada A. Subcutaneous emphysema secondary to dental treatment: Case report. Med Oral Patol Oral Cir Bucal 2007;12:E76-8.

This is an open access article distributed under the terms of the Creative Common Attribution-NonCommercial-ShareAlike 3.0 License, which allows others to remix, tweak, and build upon the work non-commercially, as long as the author is credited and the new creations are licensed under the identical terms.

\begin{tabular}{|l|l|}
\hline \multicolumn{3}{|c|}{ Access this article online } \\
\hline Quick Response Code: & Website: \\
\hline & www.ijccm.org \\
\hline
\end{tabular}

How to cite this article: Khandelwal A, Kapoor I, Prabhakar H, Mahajan C. Subcutaneous hematoma following subcutaneous emphysema: An occult association. Indian J Crit Care Med 2017;21:618-9.

C 2017 Indian Journal of Critical Care Medicine | Published by Wolters Kluwer - Medknow 